collected both in flower and fruit were preserved in alcohol, and were most painstakingly investigated at Prof. de Bary's botanical laboratory at Strassburg. The only portion of the life-history of these plants left for future investigators is the germination of their seeds, which, probably, does not take place until the first quarter of the year. The stem structure is simple. Of the presence of sieve-tubes in the bundles there appears to be no doubt. The mode of the tissue formation at the tips of the roots is peculiar; from an initial group of cells underneath the root-cap, there issues three distinct tissues. This corresponds to the third type of Janczewski, who, among the monocotyledons, found it only in Elodea. The scale and foliage leaves are described in detail. The epidermal layer is peculiar; stomates are to be found in neither of the species. The floral axis is short and axillary; there is a double-leaved spathe. The author is inclined with Ascherson to consider the plants diœcious. The anther cavities are filled with a mass of confervoid pollen. These pollen cells are found to be united in long strings, each string apparently continuous through the greater part of the length of the cylinder. The partition walls between adjacent cells in a string are transverse. The ovary is inferior and contains many ovules. The autbor suggests the morphological identity of the stamens and carpels, "the same phyllomes (or the phyllomes from the same nodal regions), which, in the male form stamens, in the female form carpels." A technical and emended character to the genus and of the two species concludes this paper.

AMERICAN APHIDES.-Dr. Riley gives a detailed account of the life-history of some species of gall-making Pemphiginæ (Art. I, vol. v. Bulletin of the United States Geological and Geographical Survey of the Territories, 1879). The facts concerning these Aphides have a special interest on account of the close relationship between the insects of this group and the now notorious grape vine Phylloxera. The special history of Schizoneura americana, n. sp., is given. It is to be found curling and gnarling the leaves of the White Elm (Ulmus americana), and passes from the egg state through no less than seven stages, in some winged, in some wingless, but in all agamic until the seventh, when, as the result of fertilisation, the true egg state is again reached. Another very common gall described is that formed by Colopha ulmicola, and the diagnoses of five new species of Pemphigus are given. In a second part of this paper Mr. Monell describes several new species, and gives detailed synonymy of several already described. Two excellent plates accompany Dr. Riley's notes on the gall-making forms.

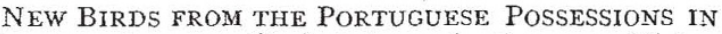
Western Africa.-Prof. Barboza du Bocage publishes (Journ. de Scien. Math. Phys. Natur., Nos. xxiii. and xxiv., Lisboa, 1878) his sixteenth and seventeenth lists of birds from Angola. A new genus and species (Hylypsornis salvadori) is established for a creeper, and a pretty sun-bird is called after M. d'Anchieta, who has added so much to our knowledge of the birds of Angola (Nectarinia anchieta). Several other new species are described in the sixteenth list. In the seventeenth list a new genus and many additional new species are also established, the more remarkable being a sun-bird (Nectarinia oustaleti) and a unique bird from Caconda (Sharpia angolensis), called after Mr. Sharpe, of the British Museum, and having affinities with Hyphantornis.

\section{A UNIVERSAL CATALOGUE}

THE Council of the Society of Arts, probably the most practically useful body in the kingdom, has taken a positive step towards the accomplishment of a task which certainly deserves to be called gigantic. We need not moralise once more on the extent to which the making of books has been carried; many a modern Solomon bas no doubt been appalled into silence in the effort even to realise, far less to express, the extent of this manufacture. To attempt to begin $a b$ initio to catalogue the works published during the past century, or even since the beginning of the present century, would be a task which to us would seem to be hopelessly endless. Any one whose business it is to work with books, and even the most thoroughgoing scientific worker must refer to them occasionally, must recognise the immense advantage, however, of having in one properly arranged catalogue, as complete a list as possible of printed books, and the farther back it went, the more valuable it would be. It is, then, certainly a fortunate thing that there exists ready to hand, though unprinted, a catalogue which for all practical purposes may be regarded as a universal catalogue of printed books, and that not only for the past century, but the past four centuries and more; for the British Museum Catalogue begins as far back as I450. Some time ago the Society of Arts considered the advisability and practicability of constructing a catalogue coming down to the year 1600 . The Council addressed a series of questions to them likely to give useful answers, and afterwards met to hear evidence on the subject. Mr. Bullen and other authorities were thus examined, and it seems to have been Mr. Bullen who happily suggested that the best and only stre method of laying a solid foundation for the Universal Catalogue of English printed literature would be to print the Catalogue of the Printed Books in the British Museum, from A.D. 1450 to the present time, say, the end of the year 1878 , representing about $1,250,000$ vols., and comprising between $2,000,000$ and $3,000,000$ entries, i.e., main titles and cross references. He considered the work might be ready for printing, "in a rough and ready way," in two years, and in less time if more force were employed, and that it would take five years to print. All the witnesses agreed that the printing of the British Museum Catalogue would be highly desirable, and the Committee are of the same opinion.

As we have had occasion to point out in these pages, the British Museum Catalogue is by no means perfect, and it is specially difficult for a man in search of a scientific serial or paper to get at it without much roundabout hunting from one cross reference to another, much waste of time, and loss of temper. Still considering all the difficulties in the way of constructing a perfectly new catalogue, we do not think a better course could be followed than that suggested by the Society of Arts' Council. It might be possible to introduce some improvement in arrangement during the process of printing, and especially with reference to the arrangement of the publications of scientific societies, which at present is so completely unscientific. It must also be borne in mind that the Catalogue is only one of authors, and that for many purposes of research such a catalogue is of little use without an equally complete one of subjects. Still the want of the latter is no argument against the publication of the former, though we should hope that the one would be followed by the other.

Of course such a stupendous, and, at its cheapest, costly undertaking could hardly be accomplished by any private body, and it is natural that the Society of Arts should look to government for help in the matter. As the scheme has the approval of the President of the Society, the Prince of Wales, we should think that the Government is not likely to hesitate in granting such aid as might be required. Of course the printing and paper need not be luxurious nor expensive, and the specimenpage issued by the Society seems to us satisfactory. It is calculated that the British Museum Catalogue would thus occupy about forty-five volumes of 1,000 pages each, and could be issued through the Stationery Office at about $16 s$. per vol., and even less if the edition were of 2,000 copies. No doubt a fair sale would be obtained for such a publica- 
tion both at home and abroad, for take it all in all, as Mr. Bullen says, "no catalogue in the world, whether in print or in manuscript, is equal to that of the British Museum." We hope, therefore, that the proposal of the Society will speedily meet with a favourable response from Govern-

\section{A MIRROR BAROMETER}

M. LÉON TEISSERENC DE BORT has invented an aneroid mirror barometer, which is described in a recent number of $L a$ Nature. It is based on a method analogous to that well-known since the researches of Gauss for the reading of small rotations. M. Teisserenc de Bort has sought to obtain an aneroid barometer which will give precise observations at sea, especially in rough weather, when it is impossible to read the mercury barometer. The principle of this barometer is very simple. The elastic tub or box B carries, as in most aneroids, a metallic point, which follows its movements. In the ment, and that should it be decided to print the British Museum Catalogue, some plan will be formed by which proofs may be revised not only by qualified bibliographers, but that the various departments of literature, science, and art will be represented on the staff of revisers.

ordinary aneroid the transformation of the vertical move ment into a rotating movement necessitates either a chain or a curb, or a sort of fork which works in a spiral furrow cut in the axis which supports the needle. These various systems have the inconvenience of producing frictions; some of them are liable to dust and rust. In the mirror barometer, the transformation of the movement is obtained by the simple contact of a small palette supported on the axis of the mirror and of the point spoken of above. As the angle which the plane of the mirror may describe does not exceed $12^{\circ}$ on each side of the vertical, it follows that the contact of the point in the palette is always precise.

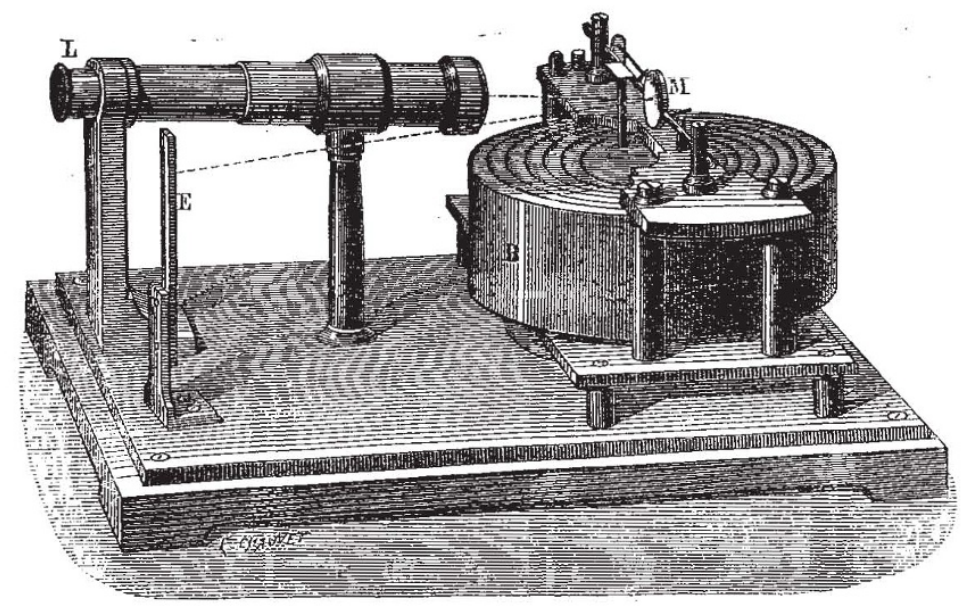

Teisserenc de Bort's mirror barometer.

As to the amplification of the movements necessary to enable us to appreciate millimetres and their fractions, this is obtained by reading with i'se aid of a small reticled telescope, $\mathrm{L}$, the image of a rraduated scale $\mathrm{E}$ which is reflected in the mirror $M$. By combining the enlargement of the telescope with th distance of the scale from the mirror, we succeed in giving to the apparatus a length of less than $20 \mathrm{~cm}$. by $\mathrm{I} 2$, which renders it quite portable. It is important to remark that the amplification of the movements of the box, which, in ordinary barometers, is obtained by means of several levers, is obtained here by an optical process; it follows that the numerous frictions and the time lost in contacts are mostly eliminated. There remains only a single movement, that of the axis which bears the mirror; in the barometer figured the pivots are of steel and the cap of platinum, and in order to avoid rust, the whole is nickel-plated.

M. Teisserenc de Bort proposes to construct others, in which the axis will be mounted on rubies. This garniture will not sensibly increase the price of the apparatus. This instrument is too new to allow us to appreciate the full degree of precision which it can attain. In a trial in a captive balloon by Capt. Perrier of several aneroids as compared with the mirror, the latter showed a great sensibility, and it quickly resumed its original position on landing.

\section{BUTTERFLIES WITH DISSIMILAR SEXES} NATURALISTS have long been familiar with the Nact that the two sexes of certain species of lepidoptera often differed from each other in colour and marking, and sometimes in form and size to a very considerable extent. For this phenomenon the convenient term "Antigeny" has been proposed by Mr. S. H. Scudder. ${ }^{\text {I }}$ In accordance with Darwin's theory of sexual selection we find that when the sexes of a butterfly differ to any marked extent in colour, it is generally the male which is the more gaudily coloured, although there are certain genera in which the reverse obtains; but, as I pointed out in NATURE (vol. iii. p. 508), there is reason to believe that in these exceptional cases the males may be

$$
{ }^{x} \text { Proc. Amer. Acad., xii. } x 5 .
$$

the selecting sex. Mr. Charles Darwin having recently called my attention to a paper on this subject in Kosmos, by that most philosophical entomologist, Fritz Müller, I have thought that an abstract might interest readers of NATURE.

The species of which the author treats, Epicalia acontizs, has such very dissimilar sexes that Fabricius described them as distinct species, calling the male Antiochus and the female Medea, while in Doubleday and Westwood's "Genera of Diurnal Lepidoptera" the two sexes are placed in different genera, the male in Epicalia and the female in Myscelia. It is not known with certainty who first pointed out that Antiochus and Medea were the sexes of the same species; but this fact is now $I$ "Epicalia acontius. Ein ungleiches Ehepaar," Kosmos, January, 1879, 